\title{
SIMULASI RUTE ALTERNATIF BERBASIS ASAL DAN TUJUAN PERJALANAN UNTUK MENGURAI KEMACETAN
}

\author{
Oleh: ${ }^{1}$ Tomi Tristono, ${ }^{2} \mathrm{M}$ Sidqon \\ ${ }^{1}$ Fakultas Teknik - Universitas Merdeka Madiun \\ ${ }^{2}$ Fakultas Teknik - Universitas 17 Agustus Surabaya \\ e-mail: 'tomi_tristono@yahoo.com, ${ }^{2}$ suud_2002@yahoo.com
}

\begin{abstract}
Abstrak:
Artikel ini berisi tentang kepadatan lalulintas pada persimpangan jalan yang bersinyal. Pada salah satu lengan jalannya terdapat jalur kereta api. Level of service $(L o S)$ dari simpangan bersinyal terhadap lampu lalulintas normal berada pada level D. Hal tersebut menunjukkan ada kemacetan di selatan dan utara lengan persimpangan setelah palang pintu kereta api diturunkan. Level of service $(L o S)$ ketika kondisi tersebut terjadi menurun ke level F. Permasalahan ini akan diselesaiakan dengan simulasi dalam hal ini menggunakan model graph dimana akan dibuat sebuah fly over baru yang melintasi persimpangan dan jalur kereta api. fly over digunakan untuk semua jenis kendaraan kecuali bukan kendaraan bermotor (UM). Level of service (LoS) kemudian naik ke level C dan ke level D setelah palang pintu kereta api diturunkan.
\end{abstract}

Key Words: Persimpangan bersinyal, Jam sibuk, Level of Service (LoS), graph.

\section{Pendahuluan}

Isu terpenting dari kajian ini adalah masalah kemacetan dan untaian jaringan jalan yang tak mampu mengakomodasi permintaan lalu - lintas. Beberapa metode telah digunakan dalam pengembangan untaian jaringan transportasi yang diprioritaskan untuk mengantisipasi pertumbuhan jumlah kendaraan. Salah satunya yaitu dengan pendekatan konvensional yang menitikberatkan pada pembangunan fisik seperti pelebaran jalan serta sarana prasarana. Sudah selayaknya dipikirkan suatu terobosan baru yaitu dengan manajemen lalu - lintas untuk mencari solusi berbagai masalah transportasi khususnya di wilayah perkotaan [6].

Salah satu bentuk untaian jaringan transportasi yang rawan kemacetan di perkotaan adalah simpang/ persimpangan. Menurut Khisty dalam Juniardi [7], simpang didefinisikan dengan dua jalan atau lebih yang bergabung atau bersimpangan, termasuk jalan dan fasilitas yang berada di tepi jalan yang mempengaruhi pergerakan lalu - lintas yang termuat di dalamnya.

Pada simpang maka arus kendaraan yang melintas akan berpotongan pada beberapa titik konflik. Konflik akan 
menghambat pergerakan dan merupakan lokasi yang rawan terjadi kecelakaan. Arus kendaraan yang terjadi pada daerah konflik mempunyai banyak permasalahan. Setiap kendaraan yang bergerak lurus ataupun berbelok ke kiri dan yang berbelok mengarah ke kanan masing-masing berhadapan dengan jenis konflik yang berbeda [5].

Simpang bersinyal merupakan bagian dari sistem kendali waktu tetap untuk simpamg di wilayah perkotaan. Pada umumnya penambahan sinyal tersebut dipergunakan untuk beberapa alasan, diantaranya yaitu untuk menghindari kemacetan simpang akibat adanya konflik arus lalu - lintas, memberi kesempatan kendaraan lain/ pejalan kaki untuk memotong jalur utama, dan mengurangi jumlah kecelakaan [2].

Kinerja simpang bersinyal dapat ditinjau dari tundaan perjalanan dan kapasitas sisa simpang. Tundaan juga dapat mengindikasikan Indeks Tingkat Pelayanan (ITP) suatu simpang [4].

Tabel 1. Indeks Tingkat Pelayanan \& Tundaan Henti Rata - rata

\begin{tabular}{|c|c|}
\hline $\begin{array}{c}\text { Tingkat } \\
\text { Pelayanan }\end{array}$ & $\begin{array}{c}\text { Tundaan Henti Rata }- \text { rata } \\
\text { (detik / kendaraan) }\end{array}$ \\
\hline A & $\leq 5,0$ \\
\hline B & $5,1-15,0$ \\
\hline C & $15,1-25,0$ \\
\hline D & $25,1-40,0$ \\
\hline E & $40,1-60,0$ \\
\hline F & $\geq 60,0$ \\
\hline
\end{tabular}

Sumber : Highway Capacity manual [2]

Kemacetan yang dikaji berada di simpang bersinyal empat lengan dengan posisi 100 meter di timur stasiun kota Jombang. Permasalahan menjadi rumit karena pada bagian lengan selatan simpang tersebut terdapat perlintasan kereta api. Palang pintunya akan ditutup dan dibuka kembali saat bila kereta api telah selesai melintas. Interval waktu penutupannya kadang mendekati dua kali siklus sinyal lampu lalu - lintas dimana setiap siklus mempunyai durasi waktu 75 detik. Pada saat usai kereta melintas maka terjadi penumpukan kendaraan yang bergerak dari arah utara ke selatan dan sebaliknya. Arus kendaraan tersebut $70 \%$ lebih didominasi oleh sepeda motor (MC) dan harus memotong jalur utama dari timur yang bergerak searah dengan dominasi kendaraan berat (HV) dan mobil penumpang (LV) [5]. Perlu diketahui juga bahwa jalur 
95 | al-Khwarizmi, Volume III, Edisi 1, Maret 2015, Hal. 93 - 106.

utara/ selatan menghubungkan Jombang dengan Malang, Pare di selatan dengan Babat, Lamongan, dan wilayah pantura. Jalur utama dari timur merupakan jalur yang menghubungkan wilayah di timur Jombang yaitu Surabaya dan sekitarnya dengan Kediri Solo, Madiun, dan Yogyakarta [8].

Analisa arus, volume, dan jalur lalu - lintas kendaraan dilakukan dengan pemodelan graf. Graf terdiri atas garis dan simpul yang dapat pula dilengkapi dengan arah, bobot dan warna. Tujuan graf itu sendiri adalah merupakan sarana visualisasi objek objek agar menjadi mudah dimengerti [3].

\section{Metode Penelitian}

Adapun tahapan langkah - langkah metode penelitian untuk melaksanakan kegiatan penelitian ini yaitu :

a. Studi literatur

b. Survey awal kondisi geometrik simpang, kapasitas simpang, volume arus lalu-lintas harian rata - rata, dan karakteristik arus lalu - lintas kendaraan.

c. Survey tentang penutupan palang pintu kereta api dan arus kendaran pada saat setelah dibuka kembali.

d. Analisa hasil survey dan ekstraksi data.

e. Membuat model graf arus lalu lintas.

f. Merencanakan Rute alternatif baru arus lalu - lintas kendaraan dengan model graf.

\section{Hasil \& Pembahasan}

\section{a. Survey Volume Kendaraan}

Posisi simpang bersinyal lokasi penelitian berada 100 meter di timur stasiun kereta api Jombang Kota atau Alun - alun Kabupaten Jombang. Simpang berada pada keadaaan kondisi geometrik datar dan mempunyai 4 lengan. Perlintasan kereta api berada di lengan selatan yaitu jalan Hasyim Asy'ari. Lengan timur adalah jalan Gatot Subroto, arus lalu - lintasnya bergerak searah memasuki simpang. 


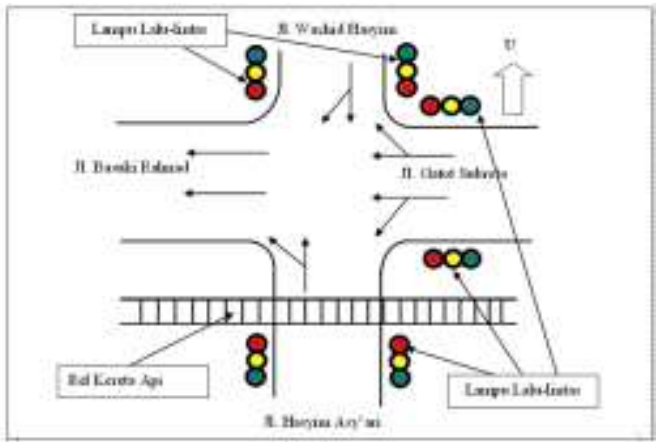

Gambar 1. Lokasi Penelitian [5]

Bila arus lalu - lintas kendaraan pada simpang lokasi penelitian pada Gambar 1. di atas disajikan dengan model graf maka ilustrasinya seperti tampak pada Gambar 2.

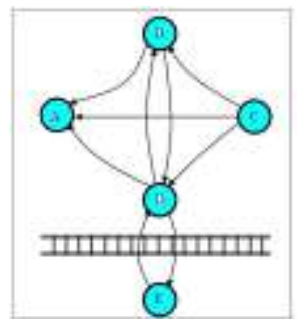

Gambar 2. Model Graf. [5]

Tampak pada Gambar 2, simpul A menyata-kan zona lengan jalan Basuki Rahmat di barat. Zona jalan Wachid Hasyim adalah lengan utara simpang dan dinyatakan dengan simpul B. Selanjutnya simpul C menyatakan lengan timur yaitu zona jalan Gatot Subroto. Simpul D adalah zona ujung jalan Hasyim Asy'ari yang berada di utara palang pintu kereta api, sedangkan simpul E zona yang terletak di selatan perlintasan rel kereta api. Sinyal lampu lalu - lintas berada di simpul E.

Arah panah menyatakan arah lalu - lintas kendaraan. Volumenya dinyatakan dengan bobot masing - masing busur. Survey dilakukan hari Sabtu, 16 Nopember 2013. Keadaan lalu lintas kendaraan saat itu sangat padat karena bertepatan dengan week end. Kendaraan dari simpul $\mathrm{C}$ bergerak satu arah yang mendekati simpang didominasi kendaraan berat (HV) dan sebagian kendaraan ringan (LV). Kendaraan tersebut pada umumnya berasal dari kota - kota di timur wilayah Jombang, yaitu Surabaya, Mojokerto dan sekitarnya. 
97 | al-Khwarizmi, Volume III, Edisi 1, Maret 2015, Hal. 93 - 106.

Kendaraan dari simpul B berasal dar Kota Jombang dan didominasi sepeda motor (MC) dan sebagian kendaraan ringan (LV). Kendaraan pada simpul E berasal dari wilayah Jombang selatan, Pare, dan Malang, sedangkan kendaraan pada simpul A bergerak searah menjauhi simpang.

Keadaan demografi dan Wilayah Kabupaten Jombang menurut data sensus pada tahun 2010 dari BPS [1] maka jumlah penduduk Kabupaten Jombang yaitu 1.201.557 jiwa yang terdiri dari 597.219 laki-laki dan 604.338 perempuan dengan laju pertumbuhan penduduk $0,64 \%$ per tahun. Kota Jombang sudah termasuk dalam klasifikasi kota besar.

Tabel 2. Hasil Survey Volume Kendaraan

\begin{tabular}{|c|c|c|c|c|}
\hline \multicolumn{2}{|c|}{$\begin{array}{c}\text { Waktu Survey Jam } \\
10.00-11.00\end{array}$} & \multicolumn{3}{|c|}{$\begin{array}{l}\text { Jumlah Kendaraan Memasuki } \\
\text { Simpang dari zona Jalan }\end{array}$} \\
\hline \multicolumn{2}{|c|}{ Jenis Kendaraan } & $\begin{array}{l}\text { Wachid } \\
\text { Hasyim }\end{array}$ & $\begin{array}{l}\text { Gatot } \\
\text { Subroto }\end{array}$ & $\begin{array}{l}\text { Hasyim } \\
\text { Asy'ari }\end{array}$ \\
\hline \multirow{2}{*}{$\begin{array}{l}\text { kendaraan } \\
\text { ringan } \\
\text { (LV) }\end{array}$} & $\begin{array}{l}\text { Kend.Prib } \\
\text { adi, } \\
\text { minibus }\end{array}$ & 129 & 593 & 324 \\
\hline & $\begin{array}{l}\text { Non Bus, } \\
\text { Angkot } \\
\text { /MPU }\end{array}$ & 35 & 6 & 35 \\
\hline \multirow{4}{*}{$\begin{array}{l}\text { kendaraan } \\
\text { berat } \\
\text { (HV) }\end{array}$} & Bus Besar & - & 37 & - \\
\hline & $\begin{array}{l}\text { Bus } \\
\text { Sedang }\end{array}$ & - & 27 & - \\
\hline & $\begin{array}{l}\text { Truck } 2 \\
\text { AS/ Box }\end{array}$ & 24 & 93 & 11 \\
\hline & $\begin{array}{l}\text { Truck } 3 \\
\text { AS / } \\
\text { Gandeng }\end{array}$ & - & 74 & - \\
\hline \multicolumn{2}{|c|}{ Sepeda motor (MC) } & 1231 & 594 & 1245 \\
\hline \multicolumn{2}{|c|}{$\begin{array}{l}\text { Kend tak bermotor } \\
\text { (UM) }\end{array}$} & 32 & 92 & 85 \\
\hline \multicolumn{2}{|c|}{ Jumlah (Q) } & 1451 & 1516 & 1700 \\
\hline
\end{tabular}

Penjabaran secara visual prosentase kendaraan pendekat simpang dari masing - masing lengan tampak pada Gambar 3 sampai dengan Gambar 5 berikut ini : 


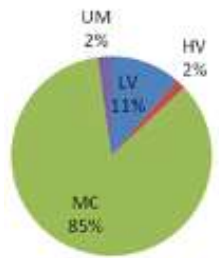

Gambar 3. Prosentase

Kendaraan Pendekat dari

Lengan Utara, zona Jl. Wachid Hasyim

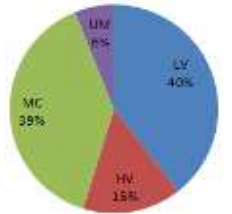

Gambar 4. Prosentase

Kendaraan Pendekat dari

Lengan Timur, zona Jl. Gatot

Subroto

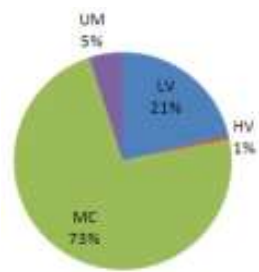

Gambar 5. Prosentase Kendaraan Pendekat dari Lengan Selatan zona Jl. Hasyim Asy’ari.

Prosentase kendaraan dari arah utara dan selatan terbesar adalah sepeda motor (MC) yaitu masing - masing sebanyak 85\% dan $73 \%$, sedangkan dari lengan timur maka dominasi yaitu pada kendaraan ringan (LV) dan kendaraan berat (HV). Jumlah prosentase keduanya yaitu 55\%. Selengkapnya tergambar pada Gambar 6 berikut ini:

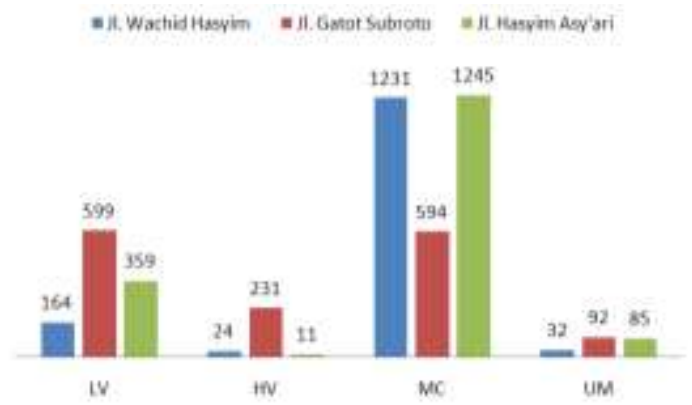

Gambar 6. Volume Kendaraan Setiap Lengan.

Penyajian secara graf berbobot untuk pergerakan jenis kendaraan ringan (LV), kendaraan berat (HV), dan sepeda motor (MC) divisualkan pada Gambar 7, Gambar 8, dan Gambar 9. Kendaraan tak bermesin atau unmotorized vehicles (UM) yang 
99 | al-Khwarizmi, Volume III, Edisi 1, Maret 2015, Hal. 93 - 106.

termasuk di dalamnya yaitu sepeda pancal, gerobak dorong, becak ataupun becak motor tanpa plat nomor juga modifikasi tidak disertakan.
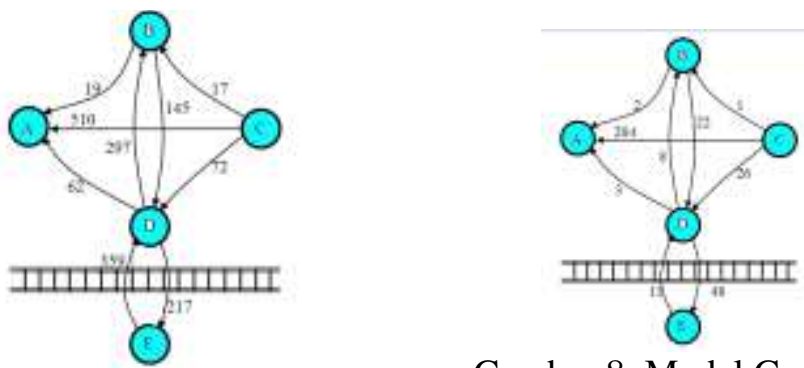

Gambar 7. Model Graf LV

Gambar 8. Model Graf HV

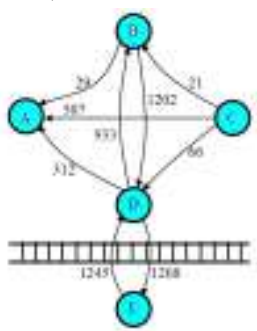

Gambar 9. Model Graf MC

Tabel. 3. Derajat Kejenuhan, Antrian \& Angka Henti.

\begin{tabular}{lcccccc}
\hline $\begin{array}{l}\text { Pen- } \\
\text { dekat }\end{array}$ & $\begin{array}{c}\mathrm{C} \\
(\mathrm{smp} \\
\text { /jam })\end{array}$ & $\begin{array}{c}\text { Q } \\
\text { (smp }\end{array}$ & DS & $\begin{array}{c}\text { NQ-1 } \\
(\mathrm{smp})\end{array}$ & $\begin{array}{c}\text { NQ-2 } \\
(\mathrm{smp})\end{array}$ & $\begin{array}{c}\mathrm{NS} \\
(\mathrm{smp})\end{array}$ \\
\hline Utara & 726.55 & 441.4 & 0.61 & 0.27 & 7.65 & 0.75 \\
\hline Timur & 1742.93 & 1018.1 & 0.58 & 0.20 & 14.86 & 0.64 \\
\hline Selatan & 685.56 & 622.3 & 0.91 & 3.93 & 16.18 & 1.12 \\
\hline
\end{tabular}

Pada Tabel 3, C yaitu kapasitas masing - masing lengan. Q adalah volume kendaraan yang melintas dengan satuan mobil penumpang (smp). Total angka dalam Tabel 3 diperoleh yaitu dengan mengalikan jumlah unit dan masing - masing rasio, untuk kendaraan ringan (LV) adalah 1, kendaraan berat (HV) adalah 1.3, sepeda motor (MC) adalah 0.2, dan kendaraan tak bermotor (UM) diabaikan.

Derajat Kejenuhan (DS) pada lengan selatan sebesar 0.91 sudah mendekati nilai arus lalu - lintas jenuh yaitu 1. Derajat kejenuhan untuk semua lengan lebih besar dari 0.5 .Arti angka tersebut yaitu pada setiap siklus sinyal lampu lalu - lintas menyala 
hijau hingga selesai maka masih terdapat sisa kendaraan yang belum melintasi simpang dan dinyatakan dengan NQ-1. Kendaraan itu boleh melanjutkan perjalanan bila lampu lalu - lintas telah menyala hijau kembali pada siklus berikutnya.

NQ-2 menyatakan kendaraan yang datang selama lampu lalulintas menyala merah. NS menyatakan angka henti yang merupakan penjumlahan dari NQ-1 dan NQ-2.

Tabel 4. Siklus Pengaturan Sinyal lampu Lalu-Lintas

\begin{tabular}{cccccc}
\hline & & \multicolumn{2}{c}{ Inter Green } & & \\
\cline { 3 - 4 } Fase & $\begin{array}{c}\text { Hijau } \\
\text { (detik) }\end{array}$ & $\begin{array}{c}\text { Kuning } \\
\text { (detik) }\end{array}$ & $\begin{array}{c}\text { Merah } \\
\text { semua } \\
\text { (detik) }\end{array}$ & $\begin{array}{c}\text { Merah } \\
\text { (detik) }\end{array}$ & $\begin{array}{c}\text { Siklus } \\
\text { (detik) }\end{array}$ \\
\hline 1. & 29 & 2 & 2 & 44 & 75 \\
\hline 2. & 38 & 2 & 2 & 35 & 75 \\
\hline
\end{tabular}

Sumber : data primer hasil survey.

Fase 1 mengatur arus kendaraan dari lengan utara dan selatan, sedangkan fase 2 mengatur kendaraan dari lengan timur.

Indek Tingkat pelayanan (ITP/LoS) simpang pada siklus normal lampu lalu - lintas yaitu pada level D, kondisi lalu - lintas telah mendekati tak stabil.

b. Volume Kendaraan Sesudah KA Lewat.

Rata - rata penutupan palang pintu kereta api dalam sehari yaitu mendekati 95 detik. Waktu tersebut jelas melebihi waktu satu siklus lampu lalu - lintas. Tundaan rata - rata perjalanan total dari semua lengan yaitu 9 menit 38 detik per satu satuan mobil penumpang. Indek Tingkat Pelayanan (ITP/LoS) simpang menjadi berada pada level $\mathrm{F}$ yaitu arus kendaraan terhambat, terjadi antrian yang panjang, dan kemacetan yang parah.

c. Analisa Permasalahan.

Arus lalu - lintas kendaraan yang berasal dari lengan selatan dan melanjutkan perjalanan ke lengan utara pada 1 jam durasi kajian untuk kendaraan ringan (LV) yaitu sejumlah 297 kendaraan, untuk kendaraan berat (HV) yaitu sejumlah 8 kendaraan, dan untuk sepeda motor (MC) adalah sejumlah 933 kendaraan. Kendaraan UM diabaikan.

Arus lalu - lintas kendaraan dari lengan utara yang melanjutkan perjalanan ke lengan selatan untuk kendaraan ringan (LV) yaitu sebanyak 145 kendaraan, untuk kendaraan berat (HV) sebanyak 22 kendaraan, dan sepeda motor (MC) sebanyak 1202 kendaraan. Kendaraan yang mendominasi melintasi simpang dari 
101 | al-Khwarizmi, Volume III, Edisi 1, Maret 2015, Hal. 93 - 106.

utara ke selatan dan sebaliknya yaitu sepeda motor (MC) keduanya berjumlah sebesar 2135 kendaraan.

Arus kendaraan yang meyeberangi simpang dari lengan timur yang menuju lengan barat ataupun yang berbelok ke lengan utara untuk kendaraan ringan (LV) sebesar 527 kendaraan, untuk kendaraan berat (HV) yaitu sebanyak 205 kendaraan, dan sepeda motor (MC) yaitu sebanyak 528 kendaraan. Dominasi jenis kendaraan yang melintas yaitu pada kendaraan ringan (LV) dan kendaraan berat (HV) sebanyak 731. Kendaraan berat (HV) didominasi bus besar jurusan Kediri, Solo dan Yogyakarta, bus sedang yang menuju Babat/ Lamongan, serta truk 2 as, box, juga truk 3 as/ gandeng.

Perlu dicermati pula tentang para pengendara sepeda motor dari lengan utara/ selatan yang pada umumnya memiliki tingkat kedisplinan dan kepatuhan pada rambu - rambu lalu lintas yang rendah. Sesaat palang pintu kereta dibuka, spontan mereka memotong arus kendaraan dari timur meskipun saat sinyal lampu lalu lintas masih menyala merah.

Solusi yang dipilih peneliti yaitu dengan alternatif rute baru berbasis asal kendaraan dan tujuan (origin and destination) kendaraan agar dapat mengurai kemacetan saat pengaturan dengan lampu lalu - lintas regular terlebih lagi saat pembukaan palang pintu sewaktu kereta api selesai melintas. Rute baru menghubungkan simpul B dan simpul E.

d. Alternatif Rute Baru $L V \& H V$

Mobil dari lengan utara yang diperkenankan menuju lengan selatan adalah Kendaran penumpang (LV) dan kendaraan berat (HV). Kendaraan angkot, non bus dan MPU harus berbelok ke kiri yaitu menuju lengan barat jalan Gatot Subroto. Model graf simulasi rute baru dengan pembangunan jalan layang yang menyeberangi simpang dan rel kereta api dan membujur dari utara ke selatan. Jalan layang hanya boleh dilewati oleh kendaraan mobil penumpang (LV) dan kendaraan berat (HV). Sepeda motor, angkot, non bus dan MPU tidak diperkenankan menggunakan fasilitas jalan layang tersebut.

Adapun model graf simulasinya adalah sebagai berikut : 


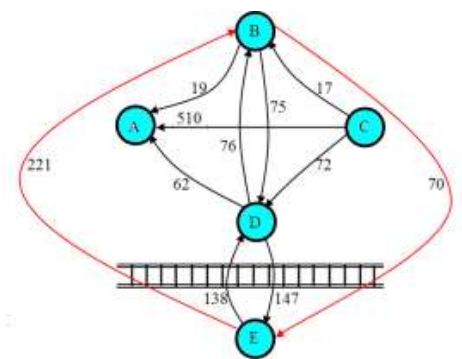

Gambar 9. Model Graf Simulasi $\mathrm{LV}$

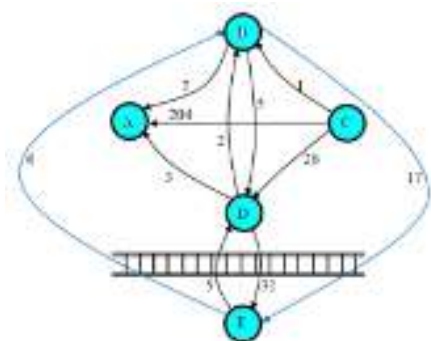

Gambar 10. Model Graf Simulasi HV

Tabel 5. Hasil Simulasi Volume Kendaraan

\begin{tabular}{|c|c|c|c|c|}
\hline \multicolumn{2}{|c|}{$\begin{array}{c}\text { Jalan Layang untuk } \\
\text { LV \& HV }\end{array}$} & \multicolumn{3}{|c|}{$\begin{array}{c}\text { Jumlah Kendaraan Memasuki } \\
\text { Simpang dari Jalan }\end{array}$} \\
\hline \multicolumn{2}{|c|}{ Jenis Kendaraan } & $\begin{array}{l}\text { Wachid } \\
\text { Hasyim }\end{array}$ & $\begin{array}{c}\text { Gatot } \\
\text { Subroto }\end{array}$ & $\begin{array}{l}\text { Hasyim } \\
\text { Asy'ari }\end{array}$ \\
\hline \multirow{2}{*}{$\begin{array}{l}\text { Kend. } \\
\text { ringan } \\
(\mathrm{LV})\end{array}$} & $\begin{array}{l}\text { Kend.Pribad } \\
\text { i, minibus }\end{array}$ & 59 & 593 & 103 \\
\hline & $\begin{array}{l}\text { Non Bus, } \\
\text { Angkot } \\
\text { /MPU }\end{array}$ & 35 & 6 & 35 \\
\hline \multirow{4}{*}{$\begin{array}{l}\text { Kend. } \\
\text { berat } \\
\text { (HV) }\end{array}$} & Bus Besar & - & 37 & - \\
\hline & Bus Sedang & - & 27 & - \\
\hline & $\begin{array}{l}\text { Truck } 2 \text { AS/ } \\
\text { Box }\end{array}$ & 7 & 93 & 5 \\
\hline & $\begin{array}{l}\text { Truck } 3 \text { AS } \\
\text { / Gandeng }\end{array}$ & - & 74 & - \\
\hline \multicolumn{2}{|c|}{ Sepeda motor (MC) } & 1231 & 594 & 1245 \\
\hline \multicolumn{2}{|c|}{$\begin{array}{l}\text { Kend tak bermotor } \\
\text { (UM) }\end{array}$} & 32 & 92 & 85 \\
\hline \multicolumn{2}{|c|}{ Jumlah (Q) } & 1364 & 1516 & 1473 \\
\hline
\end{tabular}

Pada keadaan dengan pengaturan lampu lalu - lintas normal maka :

Tabel. 6. Derajat Kejenuhan, Antrian \& Angka Henti.

\begin{tabular}{lcccccc}
\hline $\begin{array}{l}\text { Pen- } \\
\text { dekat }\end{array}$ & $\begin{array}{c}\mathrm{C} \\
(\mathrm{smp} \\
\text { /jam })\end{array}$ & $\begin{array}{c}\text { Q } \\
(\mathrm{smp}\end{array}$ & DS & $\begin{array}{c}\text { NQ-1 } \\
(\mathrm{smp})\end{array}$ & $\begin{array}{c}\text { NQ-2 } \\
(\mathrm{smp})\end{array}$ & $\begin{array}{c}\text { NS } \\
(\mathrm{smp})\end{array}$ \\
\hline Utara & 726.55 & 349.3 & 0.48 & 0.00 & 5.48 & 0.68 \\
\hline Timur & 1742.93 & 1018.1 & 0.58 & 0.20 & 14.86 & 0.64 \\
\hline Selatan & 685.56 & 393.5 & 0.57 & 0.17 & 6.46 & 0.73 \\
\hline
\end{tabular}

Keadaan lalu lintas sesudah terdapat kereta api yang lewat dengan tundaan rata - rata perjalanan 2 menit 27 detik setiap smp. 
103 | al-Khwarizmi, Volume III, Edisi 1, Maret 2015, Hal. 93 - 106.

Tingkat pelayanan simpang berada pada level F. yaitu adanya kemacetan dan antrian kendaraan yang panjang.

e. Alternatif Rute Baru Sepeda Motor (MC)

Berdasarkan pada jumlah prosentase kendaraan terbesar yang melintasi simpang dari arah utara dan selatan adalah sepeda motor (MC) maka dikonstruksi pemodelan kedua. Pemodelan kedua yaitu dengan jalan layang kecil yang disediakankan khusus untuk sepeda motor (MC). Kendaraan ringan (LV) dan kendaraan berat (HV) tidak dperkenankan melewati jalan layang. Kendaraan tak bermesin (UM) tetap tidak diperkenankan melewati jalan layang. Harapannya model kedua ini dapat menurunkan volume kendaraan yang melintas dan meningkatkan ITP/LoS simpang.

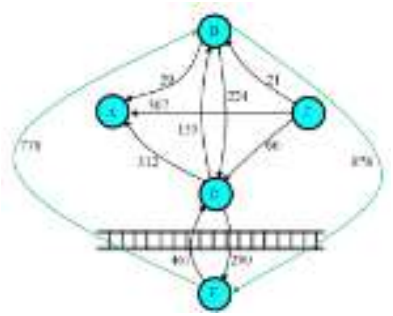

Gambar 11. Model Graf Simulasi MC

Tabel 7. Hasil Simulasi Volume Kendaraan

\begin{tabular}{|c|c|c|c|c|}
\hline \multicolumn{2}{|c|}{ Jalan Layang untuk MC } & \multicolumn{3}{|c|}{$\begin{array}{l}\text { Jumlah Kendaraan Memasuki } \\
\text { Simpang dari Jalan }\end{array}$} \\
\hline \multicolumn{2}{|c|}{ Jenis Kendaraan } & $\begin{array}{l}\text { Wachid } \\
\text { Hasyim }\end{array}$ & $\begin{array}{l}\text { Gatot } \\
\text { Subroto }\end{array}$ & $\begin{array}{l}\text { Hasyim } \\
\text { Asy'ari }\end{array}$ \\
\hline \multirow{2}{*}{$\begin{array}{l}\text { Kend. } \\
\text { ringan } \\
(\mathrm{LV})\end{array}$} & $\begin{array}{l}\text { Kend.Pribad } \\
\text { i, minibus }\end{array}$ & 129 & 593 & 324 \\
\hline & $\begin{array}{l}\text { Non Bus, } \\
\text { Angkot } \\
\text { /MPU }\end{array}$ & 35 & 6 & 35 \\
\hline \multirow{4}{*}{$\begin{array}{l}\text { Kend. } \\
\text { berat } \\
(\mathrm{HV})\end{array}$} & Bus Besar & - & 37 & - \\
\hline & Bus Sedang & - & 27 & - \\
\hline & $\begin{array}{l}\text { Truck } 2 \text { AS/ } \\
\text { Box }\end{array}$ & 24 & 93 & 11 \\
\hline & $\begin{array}{l}\text { Truck } 3 \text { AS } \\
\text { / Gandeng }\end{array}$ & - & 74 & - \\
\hline \multicolumn{2}{|c|}{ Sepeda motor (MC) } & 253 & 594 & 467 \\
\hline \multicolumn{2}{|c|}{$\begin{array}{l}\text { Kend tak bermotor } \\
\text { (UM) }\end{array}$} & 32 & 92 & 85 \\
\hline \multicolumn{2}{|c|}{ Jumlah (Q) } & 473 & 1516 & 1700 \\
\hline
\end{tabular}


Pada keadaan tidak terdapat kereta api yang lewat atau dengan pengaturan regular lampu lalu lintas maka volume kendaraan adalah sebagai berikut :

Tabel. 8. Derajat Kejenuhan, Antrian \& Angka Henti.

\begin{tabular}{lcccccc}
\hline $\begin{array}{l}\text { Pen- } \\
\text { dekat }\end{array}$ & $\begin{array}{c}\mathrm{C} \\
(\mathrm{smp} \\
\text { /jam })\end{array}$ & $\begin{array}{c}\text { Q } \\
(\mathrm{smp} \\
\text { /jam })\end{array}$ & DS & $\begin{array}{c}\text { NQ-1 } \\
(\mathrm{smp})\end{array}$ & $\begin{array}{c}\text { NQ-2 } \\
(\mathrm{smp})\end{array}$ & $\begin{array}{c}\text { NS } \\
(\mathrm{smp})\end{array}$ \\
\hline Utara & 726.55 & 245.8 & 0.34 & 0.00 & 3.61 & 0.64 \\
\hline Timur & 1742.93 & 1018.1 & 0.58 & 0.20 & 14.86 & 0.64 \\
\hline Selatan & 685.56 & 466.7 & 0.68 & 0.56 & 8.66 & 0.80 \\
\hline
\end{tabular}

Simpang pada keadaan normal dalam tingkat pelayanan katagori $\mathrm{C}$ dengan tundaan rata - rata setiap kendaraan adalah 19.27 detik. Bila terdapat kereta api yang melintas maka tundaan rata - rata meningkat menjadi 2 menit 40 detik per satuan mobil penumpang, sehingga tingkat pelayanan pada level $\mathrm{F}$ atau terjadi kemacetan dan antrian yang panjang.

\section{f. Alternatif rute Baru $L V, H V \& M C$}

Model kedua ternyata belum juga menyelesaikan permasalahan kemacetan yang terjadi pada simpang, terutama saat kereta api selesai melintas. Ketiga yaitu dengan konstruksi rute baru untuk semua kendaraan atau semua kendaraan diperkenankan melewati jalan layang kecuali kendaraan tak bermotor (UM) maka volume kendaraannya adalah sebagai berikut :

Tabel 9. Hasil Simulasi Volume Kendaraan

\begin{tabular}{|c|c|c|c|c|}
\hline \multicolumn{2}{|c|}{$\begin{array}{l}\text { Jalan Layang untuk } \\
\text { LV, HV \& MC }\end{array}$} & \multicolumn{3}{|c|}{$\begin{array}{c}\text { Jumlah Kendaraan Memasuki } \\
\text { Simpang dari Jalan }\end{array}$} \\
\hline \multicolumn{2}{|c|}{ Jenis Kendaraan } & $\begin{array}{l}\text { Wachid } \\
\text { Hasyim }\end{array}$ & $\begin{array}{c}\text { Gatot } \\
\text { Subroto }\end{array}$ & $\begin{array}{l}\text { Hasyim } \\
\text { Asy'ari }\end{array}$ \\
\hline \multirow{2}{*}{$\begin{array}{l}\text { Kend. } \\
\text { ringan } \\
(\mathrm{LV})\end{array}$} & $\begin{array}{l}\text { Kend.Pribad } \\
\text { i, minibus }\end{array}$ & 59 & 593 & 103 \\
\hline & $\begin{array}{l}\text { Non Bus, } \\
\text { Angkot } \\
\text { /MPU }\end{array}$ & 35 & 6 & 35 \\
\hline \multirow{4}{*}{$\begin{array}{l}\text { Kend. } \\
\text { berat } \\
(\mathrm{HV})\end{array}$} & Bus Besar & - & 37 & - \\
\hline & Bus Sedang & - & 27 & - \\
\hline & $\begin{array}{l}\text { Truck } 2 \text { AS/ } \\
\text { Box }\end{array}$ & 7 & 93 & 5 \\
\hline & $\begin{array}{l}\text { Truck } 3 \text { AS } \\
\text { / Gandeng }\end{array}$ & - & 74 & - \\
\hline \multicolumn{2}{|c|}{ Sepeda motor (MC) } & 253 & 594 & 467 \\
\hline \multicolumn{2}{|c|}{$\begin{array}{l}\text { Kend tak bermotor } \\
\text { (UM) }\end{array}$} & 32 & 92 & 85 \\
\hline \multicolumn{2}{|c|}{ Jumlah (Q) } & 386 & 1516 & 695 \\
\hline
\end{tabular}


105 | al-Khwarizmi, Volume III, Edisi 1, Maret 2015, Hal. 93 - 106.

Pada keadaan normal dengan pengaturan sinyal lampu lalu lintas maka tundaan rata - rata keseluruhan adalah 17.09 detik dan berada pada level $\mathrm{C}$.

Tabel. 10. Derajat Kejenuhan, Antrian \& Angka Henti.

\begin{tabular}{lcccccc}
\hline $\begin{array}{l}\text { Pen- } \\
\text { dekat }\end{array}$ & $\begin{array}{c}\mathrm{C} \\
(\mathrm{smp} \\
\text { /jam) }\end{array}$ & $\begin{array}{c}\text { Q } \\
(\mathrm{smp} \\
\text { /jam })\end{array}$ & DS & $\begin{array}{c}\text { NQ-1 } \\
(\mathrm{smp})\end{array}$ & $\begin{array}{c}\text { NQ-2 } \\
(\mathrm{smp})\end{array}$ & $\begin{array}{c}\text { NS } \\
(\mathrm{smp})\end{array}$ \\
\hline Utara & 726.55 & 153.7 & 0.21 & 0.00 & 2.14 & 0.60 \\
\hline Timur & 1742.93 & 1018.1 & 0.58 & 0.20 & 14.86 & 0.64 \\
\hline Selatan & 685.56 & 237.9 & 0.35 & 0.00 & 3.51 & 0.64 \\
\hline
\end{tabular}

Bila terapat kereta yang lewat maka tundaan perjalan menjadi 29.17 detik/ smp yaitu pada Indeks Tingkat Pelayanan D atau telah terjadi peningkatan angka Indeks Tingkat Pelayanan simpang

\section{Kesimpulan}

Model graf dapat mensimulasikan volume lalu - lintas kendaraan yang melintasi simpang. Permasalahan kemacetan lalu lintas yang sering terjadi dan terutama sesudah kereta api melintas dapat dimodelkan dengan mengkonstruksi jalan layang. Jalan layang yang membujur dari utara - selatan untuk semua kendaraan kecuali kendaraan tak bermotor (UM). Jalan layang yang merupakan rute alternatif dapat meningkatkan Tingkat Pelayanan Simpang bersinyal reguler dari semula level D ke level C, dan sesudah kereta api melintas dari level F ke level D.

Namun perlu diketahui bahwa pembangunan secara nyata sebuah jembatan layang merupakan pilihan terakhir untuk menyelesaikan perma-salahan kemacetan. Langkah pertama yang terbaik yaitu melalui manajemen lalu - lintas . Pada simpang yang diteliti perlu adanya pengaturan jadwal perjalanan dengan sinyal lampu lau - lintas yang terintegrasi dengan palang pintu kereta api. 


\section{DAFTAR PUSTAKA.}

[1] BPS, 2010, Sensus Penduduk Tahun 2010, Biro Pusat Statistik, Jakarta, Indonesia.

[2] MKJI, 1997, Manual Kapasitas Jalan Indonesia, Direktorat Jenderal Bina Marga Direktorat Bina Jalan Kota, Penerbit PT Bina Karya (Persero), Bandung, Indonesia.

[3] Siang, JJ, 2002, "Matematika Diskrit dan Aplikasinya pada Ilmu Komputer", Penerbit Andi, Yogyakarta, Indonesia.

[4] Tamin, OZ, 2000, Perencanaan Pemodelan Transportasi", Penerbit ITB, Bandung, Indonesia.

[5] Tristono, T, 2013, Studi Lalu-lintas Kendaraan di Simpang bersinyal dengan Palang Pintu Kereta Api Menggunakan Representasi Graf, Laporan Penelitian Dosen Pemula, tidak diterbitkan, Madiun, Indonesia.

[6] Priyanto, S, 2010, Atasi Kemacetan dengan Peran Manajemen Lalu Lintas, Pengukukuhkan sebagai Guru Besar Fakultas Teknik UGM, 5 Mei 2010, Yogyakarta, Indonesia.

[7] Juniardi, 2006, "Analisis Arus Lalu-lintas di Simpang tak Bersinyal", Tesis S-2 UNDIP Semarang, Indonesia.

[8] Jawa Timur, (2011), download dari wikipedia ensiklopedia bebas. 